\title{
Assessment of radio frequency heating on composition, microstructure, flowability and rehydration characteristics of milk powder
}

\author{
Yu ZHONG ${ }^{1 *}$, Yuwei WU ${ }^{1}$, Yuanrong ZHENG ${ }^{2}$, He ZHU'1, Zhenmin LIU $^{2}$, Shunshan JIAO ${ }^{1}$
}

\begin{abstract}
Radio frequency heating (RFH) provides higher efficiency and more uniform heating zone compared with conventional method. The aim of present work is to evaluate the effect of $\mathrm{RFH}$ (at $90^{\circ} \mathrm{C}$ for 5 or $10 \mathrm{~min}$ ) on the changes in composition (protein oxidation and fat distribution), microstructure, flow characteristic and rehydration property of infant milk powder. The results indicate that the concentration of protein dityrosine was slightly enhanced, more free fat appeared on powder surfaces ( $>50 \%$ increase), and porosity in powder matrix as tested by SEM was increased after RFH treatment. For powder flowability, raw sample had low cohesiveness (specific energy $=4.39 \mathrm{~mJ} / \mathrm{g}$ ), and RFH provided better flowability and decreased compressibility. Moreover, RFH had some negative impacts on wettability and solubility of powder particles with contact angle increase at least $5 \%$ and solubility decrease of $2 \% \sim 4 \%$, indicating worse rehydration abilities. Guggenheim-Anderson-de Boer (GAB) model was applied to fit moisture vapor sorption isotherms, and longer RFH duration leading to higher $c$ values (about 63\% increase at $10 \mathrm{~min}$ ). In addition, the RFH initiated browning reaction as CIE $a^{*}$ values increased from -1.8 to -1.3 .
\end{abstract}

Keywords: radio frequency heating; infant milk powder; microstructure; powder flowability; powder rehydration.

Practical Application: RFH is potentially used in post-process lethality of milk powder, thus making it critical to evaluate the influence of RFH treatment temperature and duration on bulk characteristics of milk powder when applied in post sterilization in dairy industry.

\section{Introduction}

The booming dairy industry has contributed to meet the protein, calcium and other nutritional needs of a growing global population. This requires more emerging technologies to extend shelf life of dairy product with less impact on the nutrient composition, the physicochemical characteristics and organoleptic attributes (Jermann et al., 2015). It was reported that high pressure processing (HPP), microwave heating (MWH), pulsed electric field (PEF), ultraviolet light (UV) light, and ohmic heating $(\mathbf{O M H})$ were potential technologies had been used in dairy industry (Jermann et al., 2015). Among them, HPP, PEF and UV light are non-thermal preservation techniques, and are effective against pathogens and spoilage microorganisms in liquid dairy products (Da Cruz et al., 2010; Kasahara et al., 2015). MWH and OMH could convert the electrical energy into thermal energy directly without any conduction process, and provide short heating time and more heating uniformity than conventional heating methods, which maintain the nutrition composition of the processed products well (Cappato et al., 2017; Jermann et al., 2015). Moreover, the additional effect of electroporation promotes further inactivation of microorganisms and improves safety of dairy foods (Cappato et al., 2017).

Radio-frequency heating (RFH) is a dielectric heating (DH) process just similar as $\mathrm{MWH}$, and it possesses greater penetration power than MWH (Jiao et al., 2015). RFH has been used for defrosting, thawing, drying and post-baking in food industry (Marra et al., 2009), and is developed for inactivating bacteria recently. It was reported that RFH could inactivate E. coli and Listeria innocua in milk (Awuah et al., 2005), Bacillus cereus and C. perfringens in pork luncheon meat (Byrne et al., 2006), and Clostridium sporogenes in scrambled eggs (Luechapattanaporn et al., 2005). Michael et al. (2014) displayed that $\mathrm{RFH}$ at $90^{\circ} \mathrm{C}$ for $5 \mathrm{~min}$ could thermally destruct Cronobacter sakazakii and Salmonella spp, the pathogens of most concern, in nonfat dry milk.

Powdered milk is a good nutrition resource for specific population such as infants, and is widely consumed for many convenience and preservation reasons (Fonseca et al., 2013). However, if raw milk is contaminated during processing, foodborne pathogens may still survive in low-water activity (aw) milk powder and rapidly multiply under conducive environment (Agostoni et al., 2004). Consumption of milk powder contaminated by pathogenic microbes is a major health concern even at low levels and can lead to serious illness in infants (Kent et al., 2015). Thus it is necessary to find out an effective treatment to minimize this risk of milk powder. 
Thermal sterilization of milk powder could affect its composition, microstructure, agglomerated states, bulk properties such as flow behavior, and rehydration characteristic. These properties are important for subsequent handling operations and finally influencing the consumer satisfaction. It was confirmed that RFH could be a quick post-process lethality method of milk powder before packaging (Michael et al., 2014). However, little information is known about the property-changes of milk powder after RFH treatment. Nonfat dry milk RFH at 75 to $90{ }^{\circ} \mathrm{C}$ for 5 to $125 \mathrm{~min}$ resulted in general decrease in whey protein nitrogen index and protein solubility with the color turning slightly yellow after the process. Considering the effects of RFH temperature, the $90{ }^{\circ} \mathrm{C}$ treatment was deemed to be more practical due to its short processing duration, resulting in less whey protein nitrogen index and solubility loss (Chen et al., 2013).

According to previous research, $\mathrm{RFH}$ treated milk powder at $90{ }^{\circ} \mathrm{C}$ for more than 5 min could effectively destruct the pathogens of most concern in nonfat dry milk (Michael et al., 2014). So we intend to investigate the effects of $\mathrm{RFH}$ at $90^{\circ} \mathrm{C}$ for 5 or $10 \mathrm{~min}$ on the composition changes of infant milk powder; to evaluate the flow characteristic; and to analyze the reconstitution property of powder. The results may help to deeper understand the influence of RFH treatment on the processing properties of milk power, and expand the applications of RFH in food industry.

\section{Materials and methods}

\subsection{RFH treatment of milk powder}

Wyeth gold S-26 infant milk powder (1200 g packaged) was purchased from a local supermarket. Three hundred gram of milk powder was placed in a polypropylene plastic container $\left(16.0 \mathrm{~L} \times 10.5 \mathrm{~W} \times 6.8 \mathrm{H} \mathrm{cm}^{3}\right)$ with small holes uniformly distributed on the side and bottom. The container was put in the RFH unit (GJD-6A-27-JY, Huashi Jiyuan Co. Ltd., Hebei, China) at a frequency of $27.1 \mathrm{MHz}$, power of $6 \mathrm{~kW}$, electrode distance of $85 \mathrm{~mm}$ until the temperature reached $90^{\circ} \mathrm{C}$. The sample was heated at target temperature for $5 \mathrm{~min}$ or $10 \mathrm{~min}$, and then was taken out immediately and cooled to $25^{\circ} \mathrm{C}$ by forced ambient air. The treated milk powder was vacuum packaged for further quality evaluation. The untreated milk powder was used as control sample.

\subsection{Measurement of Protein Carbonyls (PCs)}

Protein carbonyls were measured according to the method of Scheidegger et al. (2010) with some modifications. $3 \mathrm{~mL}$ of aqueous milk solution ( $2 \mathrm{mg}$ of protein) was incubated with $3 \mathrm{~mL}$ of $10 \mathrm{mM}$ 2, 4-dinitrophenyl hydrazine in $2.5 \mathrm{M} \mathrm{HCl}$. After $30 \mathrm{~min}$, milk proteins were precipitated with $1.5 \mathrm{~mL}$ of $50 \%$ (w/v) trichloro acetic acid and centrifuged at $5000 \mathrm{~g}$ for $20 \mathrm{~min}$ at $4{ }^{\circ} \mathrm{C}$. Protein pellets were washed three times with ethanol/ethyl acetate $(50: 50, \mathrm{v} / \mathrm{v})$, and re-dissolved in $3 \mathrm{~mL}$ of $6 \mathrm{M}$ guanidine- $\mathrm{HCl}$ overnight at $4{ }^{\circ} \mathrm{C}$. The solution was centrifuged at $5000 \mathrm{~g}$ for $20 \mathrm{~min}$ at $4^{\circ} \mathrm{C}$ and the absorbance of the supernatant was measured at 370 for solutions with or without DNPH, respectively. Absorbance at $370 \mathrm{~nm}$ was used to estimate protein concentration with weighed bovine serum albumin (Sigma-Aldrich Co., St. Louis, MO, USA) as a standard. Results were expressed as nmol/mg protein.

\subsection{Measurement of Protein Dityrosine (PD)}

Milk protein $(1 \mathrm{mg})$ was precipitated and re-dissolved in guanidine- $\mathrm{HCl}$ following the procedure as 2.2 section described. The presence of dityrosine in protein solutions was analyzed using an LS 55 luminescence spectrometer (Perkin Elmer, Inc., Boston, MA, USA). The increase of fluorescence with excitation and emission wavelengths of 315 and $410 \mathrm{~nm}$ was used to calculate the formation of dityrosine (Scheidegger et al., 2013). Results were expressed as arbitrary fluorescence units.

\subsection{Analysis of total fat, total free fat and surface free fat}

Total fat was determined using Soxhlet extraction with hexane as solvent. For determination of total free fat, $1 \mathrm{~g}$ of the powder was periodically mixed with $40 \mathrm{~mL}$ of petroleum ether at $25^{\circ} \mathrm{C}$ for $48 \mathrm{~h}$ (Bagga et al., 2012). The suspension was then filtered following by two more quick washes with $2 \mathrm{~mL}$ of petroleum ether. The amount of total free fat was obtained gravimetrically after solvent evaporation and recorded as the extracted fat in $\mathrm{mg}$ per $\mathrm{g}$ of powder.

Surface free fat was determined by the solvent extraction method of Bagga et al. (2012). One gram of the sample was weighed on a filter paper, placed in a glass funnel, and washed with $5 \mathrm{~mL}$ of petroleum ether for four times at $25^{\circ} \mathrm{C}$. After the filtered solvent evaporated, the amount of surface free fat was also gravimetrically obtained. The result was expressed as the mg of extracted fat per $g$ of powder.

\subsection{Scanning Electron Microscopy (SEM)}

The powder samples were conditioned in desiccators with $\mathrm{P}_{2} \mathrm{O}_{5}$ for 7 days and then coated with gold in a LDM-1000A sputter coater (Shanghai Yong Lin Electronics Equipment Co., Ltd., Shanghai, China) at 3-5mA for 150 s. Morphological observations of the sample surfaces were carried out with a S-2150 scanning electron microscope (Hitachi High-Technologies Corp., Kumagaya, Japan).

\subsection{Measurements of Powder Rheology}

Rheology of milk powder was acquired on a FT4 Powder rheometer (Freeman Technology, Gloucestershire, UK). All experiments were performed at $25^{\circ} \mathrm{C}$ and with air relative humidity of $50 \%$. Compaction property, shear property and dynamic characterization of milk powder were examined with corresponding test module.

\subsection{Determination of sorption isotherms}

Precisely weighed samples $( \pm 0.0001 \mathrm{~g}$ ) were spread on the pre-weighed Petri dishes and equilibrated in desiccators over saturated salt solutions of known water activities (CH3COOK-0.22, $\mathrm{MgCl}_{2}-0.33, \mathrm{Mg}(\mathrm{NO} 3)_{2}-0.53, \mathrm{KI}-0.68, \mathrm{NaCl}-0.75, \mathrm{KCl}-0.84$ at $25^{\circ} \mathrm{C}$ ). The samples were taken out every day to measure their weights until the mass change was less than $0.1 \%$ for two consecutive measures. Water sorption behavior was fitted with the Guggenheim-Anderson-de Boer (GAB) model. 
$\frac{M_{e}}{M_{m}}=\frac{k c a_{w}}{\left(1-k a_{w}\right)\left[1+(c-1) k a_{w}\right]}$

where $M_{e}$ was the equilibrium moisture content (g/g dry solids), $M_{m}$ was the monolayer value (g/g dry solids), $a_{w}$ was the water activity, and $k$ and $c$ were constants.

\subsection{Measurements of contact angles}

Powder sample was compressed into a $1 \mathrm{~mm}$ leveled discs(diameter of $10 \mathrm{~mm}$ ), and the contact angle of water on it was measured with an OCA 20 Contact Angle System (Data Physics Instruments $\mathrm{GmbH}$, Berlin, Germany) using the sessile drop procedure. The water droplet volume was $4 \mu \mathrm{L}$ and the contact angle value was recorded at measurement time of $5 \mathrm{~s}$.

\subsection{Measurements of conductivity}

Milk powder was added to $300 \mathrm{~mL}$ of DI water to obtain $1.5 \%(w / v)$ suspension (Crowley et al., 2015). For dynamic analysis of conductivity over $120 \mathrm{~min}$, milk suspensions were stirred at $25^{\circ} \mathrm{C}$ with $2025 \mathrm{rpm}$. Conductivity was measured using a DDS-307A conductivity meter (INESA Scientific Instrument Co., Ltd, Shanghai, China). The probe was calibrated at $25^{\circ} \mathrm{C}$ with $0.1 \mathrm{~mol} / \mathrm{L} \mathrm{KCl}$ solution $\left(12280 \mu \mathrm{S} \cdot \mathrm{cm}^{-1}\right)$.

\subsection{Solubility test}

Sample was dissolved with DI water to prepare a 5\% (w/w) solution. The solution was stirred at $400 \mathrm{rpm}$ and $25^{\circ} \mathrm{C}$ for $30 \mathrm{~min}$, and then centrifuged at $1000 \mathrm{~g}$ for $15 \mathrm{~min}$ (Semagoto et al. 2014). The supernatant was weighed and then dried at $105^{\circ} \mathrm{C}$ for $24 \mathrm{~h}$ for total solids determination. The solution before centrifugation was set as the control. The solubility was expressed as the ratio of total solids in the supernatant to those in the control solution.

\subsection{Color measurements}

Color changes were measured using a Lab Scan XE Chroma meter (Hunter lab, VA, USA) and expressed in CIE $L^{\star} a^{\star} b^{\star}$ space as follows: black to while ( $L^{\star}$ from 0 to 100 ) red to green ( $a^{\star}$ from positive to negative), and yellow to blue ( $b^{\star}$ from positive to negative).

\subsection{Statistical analysis}

Three replications were carried out for each treatment, and data were statistically analyzed with one-way ANOVA method. Significant differences $(P<0.05)$ were determined by the least significant difference test using SAS software (version 13.0, Statistical Package for the Social Sciences Inc., Chicago, USA).

\section{Results and discussions}

\subsection{Protein oxidation after processing}

Improper processing conditions during manufacture of milk products, such as exposure to light or thermal treatment, may initiate protein oxidative damage. Protein oxidation was evaluated by the changes of PCs and PD in present study. As seen in Table 1 , the PCs in milk powder was $16.9 \mathrm{nmol} / \mathrm{mg}$ protein. It was reported that PCs in raw milk was less than $1 \mathrm{nmol} / \mathrm{mg}$ protein, while powder samples exhibit ten-fold higher contents with dispersion from 8.6 to $60.9 \mathrm{nmol} / \mathrm{mg}$ protein (Fenaille et al., 2005). From Table 1, there were no significant differences of PCs between treated and control samples, reflecting that short time RFH treatment $(<10 \mathrm{~min})$ had less affection on PCs formation. However, RFH for 10 min could obviously enhance the concentration of dityrosine (a product of tyrosine oxidation), suggesting changes in the tertiary structure of proteins which lead to intra and intermolecular cross-linking (Dalsgaard et al., 2007).The technology that promotes oxidation is not promising for commercialization of dairy product (Jermann et al., 2015), thus it is necessary to shorten the RFH time.

\subsection{Masses of milk fat fractions}

The amounts of different milk fat fractions were shown in Table 1. The total fat in raw powder was $169.0 \mathrm{mg} / \mathrm{g}$, which was composed of surface free-fat, inner free-fat and encapsulated fat. It was seen that only $20.9 \mathrm{mg} / \mathrm{g}$ of the total fat was presented as free-fat, and about $12 \%$ of the free fat was located in the near surface region. It was reported that the surface of whole milk powder was locally covered with thin fat layer and the fat was mostly unprotected by protein layer (Kim et al., 2003). After RFH processing, the amount of total fat changed slightly $(\mathrm{P}>0.05)$. However, the contents of free fat especially surface free fat increased obviously. Kim et al. (2003) suggested that encapsulated fat globules were located underneath surface free fat. During process, free fat and fat globules diffused slowly towards the center of milk particles, while lactose and other molecules diffused very quickly, and the outermost surface of milk powder was consequently enriched by free fat. More free fat could contribute to greater levels of oxidation and poorer rewetting properties.

\subsection{Changes in milk powder microstructure}

Scanning electron micrographs of milk powders were displayed in Figure 1. Raw milk powder approximated spherical shape and grouped in clusters. The surface of the powder was

Table 1. Protein oxidation index and fat composition of milk powder before and after radio frequency heating*.

\begin{tabular}{|c|c|c|c|c|c|}
\hline & \multicolumn{2}{|c|}{ Protein Oxidation Index } & \multicolumn{3}{|c|}{ Fat $(m g / g)$} \\
\hline & Protein Carbonyls (nmol/mg) & Protein Dityrosine $(A U)$ & Total fat & Total free fat & Surface free fat \\
\hline Control & $16.9 \pm 0.3^{\mathrm{a}}$ & $2.0 \pm 0.0^{b}$ & $169.0 \pm 1.4^{\mathrm{a}}$ & $20.9 \pm 2.0^{\mathrm{a}}$ & $2.5 \pm 0.6^{\mathrm{b}}$ \\
\hline $5 \min$ & $16.9 \pm 0.3^{\mathrm{a}}$ & $2.1 \pm 0.0^{\mathrm{b}}$ & $163.5 \pm 2.1^{\mathrm{a}}$ & $15.5 \pm 3.4^{\mathrm{b}}$ & $4.3 \pm 0.5^{\mathrm{a}}$ \\
\hline $10 \mathrm{~min}$ & $16.1 \pm 1.0^{\mathrm{a}}$ & $2.2 \pm 0.0^{\mathrm{a}}$ & $162.5 \pm 3.5^{\mathrm{a}}$ & $16.4 \pm 2.5^{\mathrm{ab}}$ & $3.8 \pm 0.3^{\mathrm{a}}$ \\
\hline
\end{tabular}

${ }^{\star}$ Results were the mean values \pm standard deviation. Different letters in the same column indicated significant differences $(\mathrm{p}<0.05)$. 

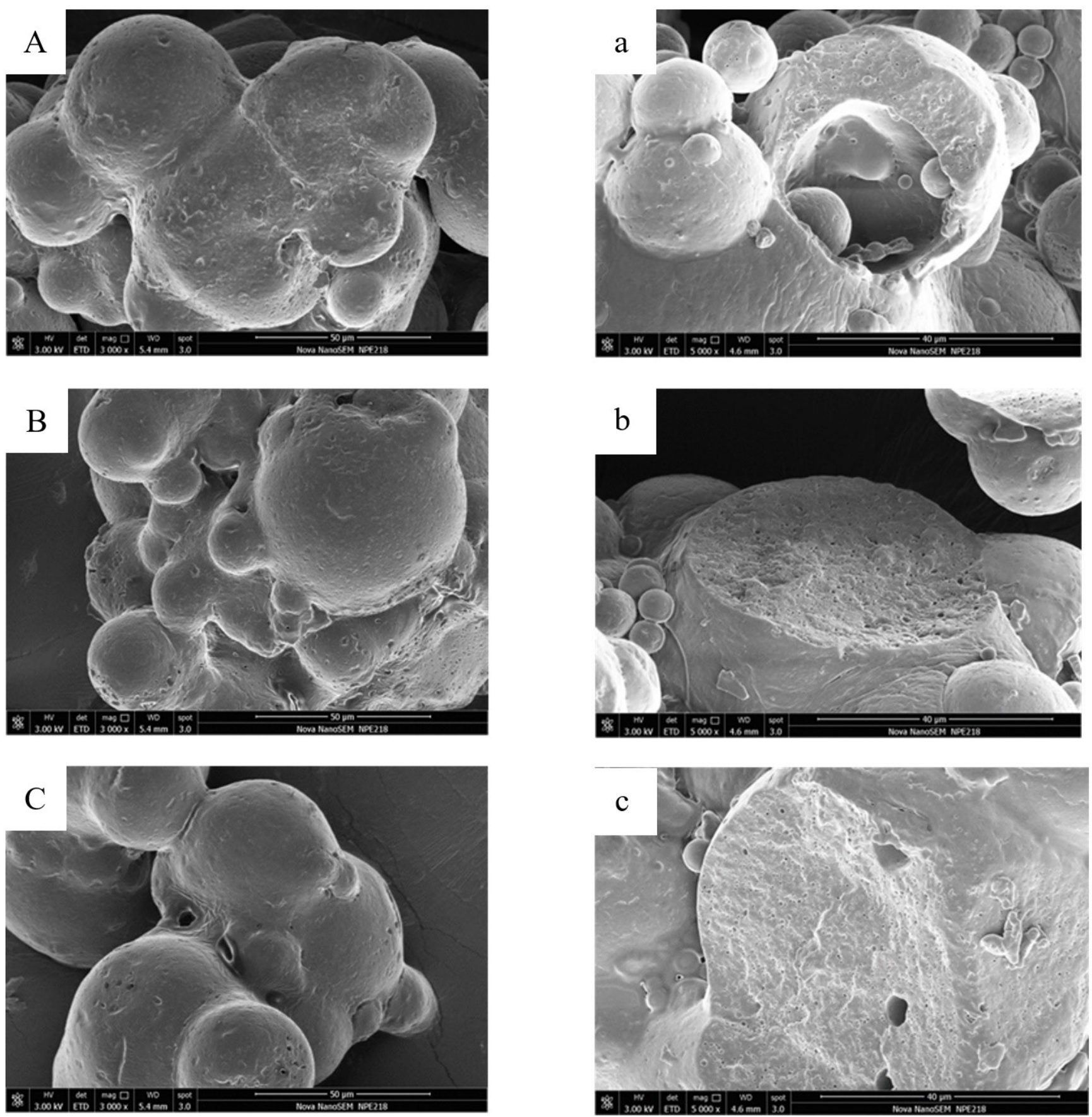

Figure 1. Microstructures of milk powder before and after radio frequency heating (A: surface topography of control sample, a: cross-section topography of control sample; B: surface topography of radio-frequency heated sample for $5 \mathrm{~min}$, b: cross-section topography of radio-frequency heated sample for $5 \mathrm{~min}$; C: surface topography of radio- frequency heated sample for $10 \mathrm{~min}$, c: cross-section topography of radio-frequency heated sample for $10 \mathrm{~min}$ ).

rough and there appeared various dents on it. It was concluded that lactose crystals coated by free fat layer would lead to the roughness of particle surface (Baechler et al., 2005). For RFH treated samples, the powder surface was smoother, the granule boundaries were fuzzier, and the gel-like regions became larger. The melting and migration of surface free fat may induce the changes of treated powders. The cross-section of the particle showed that the porosity in powder matrix was enhanced which may relate to the release of encapsulated fat onto the surface. These observations were similar to the previous research on heat-treated whole milk powder (Baechler et al., 2005) and spray-dried whey protein concentrate.

\subsection{Rheology of milk powder}

FT4 rheometer is a sensitive tool for objectively measuring bulk properties of particles, and it was used to analyze the 
compression, shear and dynamic properties of the samples in present study. Compressibility represents the ease of handling and transport, and greater values always associate with stronger cohesivity (Han et al., 2011). As summarized in Table 2, the compressibility of milk powder decreased after RFH treatment and the descent range was less than $8 \%$. Lower compressibility is a desirable property for food powders, which means less excess air in the bulk and more efficient packing among the particles (Han et al., 2011).

The value of flow function (FF), obtained from shear test, could directly reflect the flowability of sample, as FF $<1$ means not flowing; $1<\mathrm{FF}<2$ means very cohesive; $2<\mathrm{FF}<4$ means cohesive; and $4<\mathrm{FF}<10$ means easy flowing (Han et al. 2011). It was seen in Table 2 that control powder could be classified as easy flowing powder $(\mathrm{FF}=4.72)$ and the flowability was enhanced after treatment (increasing to 4.96 after 10 min treatment). Moreover, lower shear stress equates to less resistance to flow, which was the situation of the treated milk powder (less $\tau_{79 \text { and }} \tau_{39}$ ). Another parameter from the shear data, cohesion, displayed the same trend with shear stress (decreasing from 0.85 to 0.81 after $10 \mathrm{~min}$ RFH). As listed in Table 2, the results of compression test was much in agreement with the values determined in shear test, showing that the powders became easier to flow after processing. A possible explanation is that during $\mathrm{RFH}$ treatment at $90^{\circ} \mathrm{C}$, a small amount of lipid melted with moisture evaporation, forming liquid bridges among particles, and caused agglomerations of the powders, thereafter the particle sizes were lager with longer duration (seen from Figure 1). It was widely accepted that lager particle size leads to better flowability for cohesive powders (Fu et al., 2012). In addition, some fat in milk powder migrated to the particle surfaces (seen from Table 1) and reduce the friction effects among particles.

Specific energy (SE) can be used to identify how easily a powder will flow in an unconfined or low stress environment, providing a nice indication of the relative cohesion of the powder (Fu et al., 2012). Typically, for $\mathrm{SE}<5$, a powder has low cohesion; for $5<\mathrm{SE}<10$, a powder has moderate cohesion; and for SE > 10, a powder has high cohesion (Han et al., 2011). Regarding the three tested powders in this study, all of them had low cohesiveness. And the SE values of treated samples were $4.1 \%$ and $6.8 \%$ lower than that of raw material, suggesting that the formers are free flowing. The SE value is affected by the cohesive

Table 2. Flow characteristics of milk powder before and after radio frequency heating.

\begin{tabular}{lccc}
\hline \multicolumn{1}{c}{ Flow Characteristics } & Control & $5 \mathrm{~min}$ & $10 \mathrm{~min}$ \\
\hline Compressibility, $\mathrm{CPS}_{15}(\%)$ & 16.7 & 15.4 & 15.5 \\
Shear Stress, $\tau_{7,9}(\mathrm{kPa})$ & 3.51 & 3.42 & 3.15 \\
Shear Stress, $\tau_{3,9}(\mathrm{kPa})$ & 1.97 & 1.97 & 1.85 \\
Cohesion, $C_{9}(\mathrm{kPa})$ & 0.85 & 0.83 & 0.81 \\
Flow Function, FF & 4.72 & 4.80 & 4.96 \\
Basic Flowability Energy, BFE $(\mathrm{mJ})$ & 80.42 & 85.31 & 89.49 \\
Stability Index, SI & 1.02 & 1.14 & 1.09 \\
Flow Rate Index, FRI & 1.46 & 1.37 & 1.26 \\
Specific Energy, SE $(\mathrm{mJ} / \mathrm{g})$ & 4.39 & 4.21 & 4.09 \\
Conditioned Bulk Density, CBD $(\mathrm{g} / \mathrm{ml})$ & 0.48 & 0.49 & 0.51 \\
\hline
\end{tabular}

and mechanical interlocking forces among the particles, and lower cohesiveness always results in less SE values (Leturia et al., 2014). Better flowability contributes to less agglomerate, ease of handling and processing, and convenience of production and transportation for milk powder (Kim et al., 2005).As far as the basic flowability energy (BFE) is concerned, it appeared that $\mathrm{RFH}$ treatments led to greater values. The raw milk powder were more cohesive, and the particles forced to flow at the blade face were more easily accommodated by the voids that existed among agglomerates, and the stress transmission zones were thus relatively localized (Leturia et al., 2014), accounting for a low flow energy. Flow rate index (FRI) is used to assess the sensitivity to blade speed (Leturia et al., 2014), and cohesive powders are generally more sensitive. The FRI values of the powders are relatively low, ranging 1.46 to 1.26 . Moreover, all the powders had quite conditioned high bulk densities, indicating that the inter-particulate forces are small.

\subsection{Wetting behavior}

The rehydration of powders is generally composed of four steps including wetting, sinking, dispersing, and dissolving (Marabi et al., 2008). Measurement of contact angle $(\theta)$ can reflect the degree of wetting process, which only needs a small amount of liquid and a small contact surface area. The $\theta$ value of water droplet on milk powder disc decreased as a function of time according to our primary experiment, reflecting that the wetting of water is a dynamic procedure. In present study, we just determined the $\theta$ at $5 \mathrm{~s}$ to distinguish the wettability differences of the samples. It was seen from Table 3 that $\theta$ of raw sample was about $42^{\circ}$, which was more than the value of milk protein concentrate (MPC 35, lower than $30^{\circ}$ ) (Crowley et al., 2015) but lower than the value of skimmed milk powder (ca. $60^{\circ}$ ) (Ji et al., 2016). The differences may attribute to the primary-composition variations (protein, lactose and fat). After RFH treatment, $\theta$ values at $5 \mathrm{~s}$ increased significantly, indicating poorer wetting behaviors of samples. And the possible explanation was the migration of fat onto the surface as well.

\subsection{Conductivity measurements}

Conductivity is useful to investigate the release of minerals during rehydration process (Crowley et al., 2015). As seen in Figure 2 , the conductivity of raw milk solution was $562 \mu \mathrm{S} \cdot \mathrm{cm}^{-1}$, and it was reported that the primary contributor was soluble minerals while the contribution of proteins and lactose can be ignored (Ji et al., 2016). The initial conductivity raised quickly at first $10 \mathrm{~min}$ with rate of $1.86 \mu \mathrm{S} \cdot \mathrm{cm}^{-1} \cdot \mathrm{min}^{-1}$, which was induced by the release of fast-dissolving salts such as sodium and potassium. However, the conductivity increased slowly but continuously from 10 to $90 \mathrm{~min}$, which might be due to the slow-dissolving of colloidal minerals (calcium, phosphorus and magnesium) and could be used to monitor the dispersion process (Ji et al., 2016). The increment of conductivity declined after RFH treatment, and the growth rate at slow-dissolving step were $0.39,0.35$ and $0.36 \mu \mathrm{S} \cdot \mathrm{cm}^{-1} \cdot \mathrm{min}^{-1}$ for raw, $5 \mathrm{~min}$ and 10 min treated samples, respectively. According to previous data, RFH treatment promoted the migration of fat to the surfaces of milk powder, which can inhibit ion mobility and thus reduced 
Table 3. Solubility, contact angle, and color values of milk powder before and after radio frequency heating*.

\begin{tabular}{|c|c|c|c|c|c|c|}
\hline & \multirow{2}{*}{$\begin{array}{l}\text { Solubility } \\
\text { (\%) }\end{array}$} & \multirow{2}{*}{$\begin{array}{l}\text { Contact } \\
\text { angle }\left({ }^{\circ}\right)\end{array}$} & \multicolumn{4}{|c|}{ Color } \\
\hline & & & $L^{*}$ & $a^{*}$ & $b^{*}$ & $\Delta \mathrm{E}^{\star}$ \\
\hline Control & $85.6 \pm 2.4^{\mathrm{a}}$ & $42.6 \pm 2.3^{\mathrm{b}}$ & $90.0 \pm 1.3^{\mathrm{a}}$ & $-1.8 \pm 0.2^{\mathrm{b}}$ & $29.7 \pm 0.3^{b}$ & $29.9 \pm 0.4^{\mathrm{a}}$ \\
\hline $5 \mathrm{~min}$ & $83.9 \pm 0.7^{\mathrm{a}}$ & $45.0 \pm 3.2^{\mathrm{b}}$ & $89.1 \pm 0.2^{\mathrm{a}}$ & $-1.3 \pm 0.3^{\mathrm{a}}$ & $30.5 \pm 0.5^{\mathrm{a}}$ & $30.8 \pm 0.5^{\mathrm{b}}$ \\
\hline $10 \mathrm{~min}$ & $82.2 \pm 0.9^{b}$ & $48.7 \pm 4.3^{\mathrm{a}}$ & $89.1 \pm 0.5^{\mathrm{a}}$ & $-1.4 \pm 0.1^{\mathrm{a}}$ & $31.2 \pm 0.1^{\mathrm{a}}$ & $31.5 \pm 0.1^{\mathrm{b}}$ \\
\hline
\end{tabular}

${ }^{*}$ Results were the mean values \pm standard deviation. Different letters in the same column indicated significant differences $(\mathrm{p}<0.05)$.

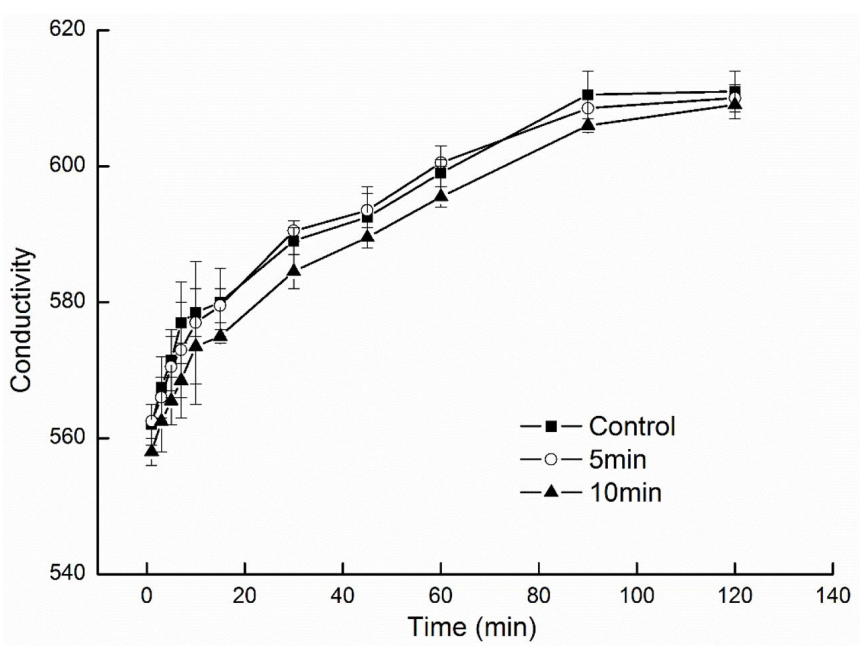

Figure 2. The conductivity change of milk powder before and after radio frequency heating.

conductivity changes. Meanwhile, the conductivity reached steady state from 90 to $120 \mathrm{~min}$, indicating the completion of mineral release. It was found that the final conductivity value of all the solutions was ca. $610 \mu \mathrm{S} \cdot \mathrm{cm}^{-1}$, confirming the complete dissolution state of each sample was similar.

\subsection{Moisture sorption isotherms}

Adsorption of moisture vapor on a solid surface corresponds to the condensational wetting process (Ji et al., 2016), which can provide some insights into the wettability of the solid. And condensational wetting procedures are generally evaluated by moisture sorption isotherms at different water activities. It was found in Figure 3 that the isotherms exhibited sigmoid shape and the powders adsorbed more moisture with water activity increased. In addition, there was less variation in moisture content from the water activity of 0.53 to 0.68 , whereas the increase trend was enhanced remarkably at water activities above 0.68 . Ji et al. (2016) attributed less change in moisture adsorption at mediate water activity to lactose crystallization. As seen in Figure 3, the treated and raw powders displayed no significant differences in the isotherm data. Thus GAB model was applied to fit moisture sorption behavior to further explore disparities using Equation 1. $M_{m}$ is a critical water content for food below which the materials are most stable. $M_{m}$ was $0.0184 \mathrm{~g} / \mathrm{g}$ dry solids for control sample, and the values were 0.0181 and $0.0188 \mathrm{~g} / \mathrm{g}$ dry solids for 5 and $10 \mathrm{~min}$ treated samples. The $k$ constant represents a correction factor for multilayer molecules relative to the bulk liquid (Sormoli \& Langrish, 2015), and its value approached 1 for each powder suggesting the heat of evaporation

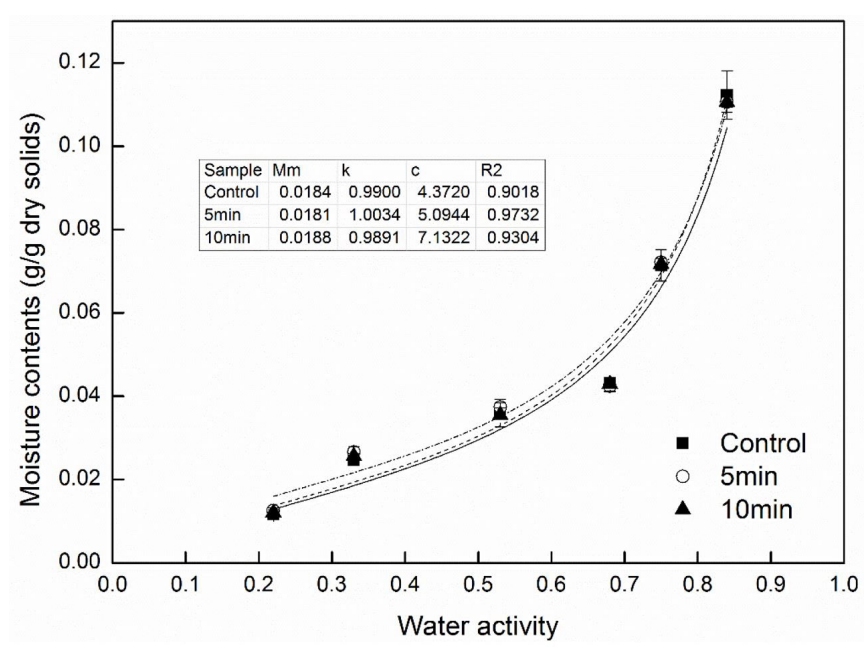

Figure 3. Moisture vapor adsorption isotherms of milk powder before and after radio frequency heating.

for multilayer molecules is similar with pure water (Sormoli \& Langrish, 2015). The parameter of $c$ is related to water-substrate interaction energy (Sormoli \& Langrish, 2015), and the data showed relatively obvious differences in present study. The $c$ value was greater with treated time increasing, demonstrating that the powder being less hydrophilic and more energy was needed for moisture adsorption.

\subsection{Solubility}

Solubility is a critical property for dairy powder, and higher value of solubility accounts for better functional property and higher customer satisfaction (Anema et al., 2006). As shown in Table 3,the solubility of raw sample was ca. $85 \%$, and RFH treating for 5 min displayed little impact on solubility, while $\mathrm{RFH}$ treatment for 10 min induced about $4 \%$ solubility reduction which was comparable to the effect of RFH on nonfat dry milk (Chen et al., 2013). The solubility of milk powder depends on many factors including chemical composition, physical state, processing conditions, and also properties of dissolving solution (Semagoto et al., 2014). The solubility loss caused by RFH may be attributed to changes of surface composition, particle size and particle structure (particularly agglomeration).

\subsection{Color changes}

$\mathrm{CIE} L^{*} a^{*} b^{*}$ data were monitored to determine whether powder color changed during the treatment. For samples subjected to $\mathrm{RFH}$, the $a^{\star}, b^{\star}$, and $\Delta E^{\star}$ values increased markedly $(\mathrm{P}<0.05)$, especially for $a^{\star}$ value; while no obvious changes were observed 
for $L^{*}$ value $(\mathrm{P}>0.05)$. The variations of $a^{*}$ and $b^{*}$ values were closely associated with brown coloration which may be initiated by Maillard browning. $\Delta E^{\star}$ represented an indication of the overall color deviation from the standard white. As can be shown in Table 3, RFH treatment led to greater color difference in the milk powder even though there were no significant differences between two treated samples.

\section{Conclusion}

This study showed that RFH treatment could induce protein dityrosine formation and surface free fat migration of infant milk powder. Also the powder surface was smoother and powder matrix was more porous after post treatment. Subsequently, the flowability of milk powder was enhanced, while the rehydration ability was weakened with longer RFH duration as indicated by smaller contact angle, slower dissolving rate, and poorer solubility. In addition, RFH treatment for more than 5 min initiated brown colors in samples. Although RFH could produce effective sterilization for milk powder according to previous literature, its impact on processing characteristics of milk powder should not be ignored. And the RFH post-process conditions must be controlled accurately when applied in diary industry. However, the effects of RFH on nutritional and functional properties of milk powder will be further validated.

\section{Acknowledgements}

This work was supported by the Shanghai Minhang District Commission of Science and Technology (2013MH088) and the State Key Laboratory of Dairy Biotechnology, Bright Dairy \& Food Co. Ltd. (SKLDB2016-006).

\section{References}

Agostoni, C., Axelsson, I., Goulet, O., Koletzko, B., Michaelsen, K. F., Puntis, J. W., Rigo, J., Shamir, R., Szajewska, H., Turck, D., Vandenplas, Y., \& Weaver, L. T., and the ESPGHAN Committee on Nutrition. (2004). Preparation and handling of powdered infant formula: a commentary by the ESPGHAN Committee on Nutrition. Journal of Pediatric Gastroenterology and Nutrition, 39(4), 320-322. PMid:15448416. http://dx.doi.org/10.1097/00005176-200410000-00002.

Anema, S., Pinder, D., Hunter, R., \& Hemar, Y. (2006). Effects of storage temperature on the solubility of milk protein concentrate (MPC85). Food Hydrocolloids, 20(2), 386-393. http://dx.doi.org/10.1016/j. foodhyd.2005.03.015.

Awuah, G., Ramaswamy, H., Economides, A., \& Mallikarjunan, K. (2005). Inactivation of Escherichia coli K-12 and Listeria innocua in milk using radio frequency (RF) heating. Innovative Food Science \& Emerging Technologies, 6(4), 396-402. http://dx.doi.org/10.1016/j. ifset.2005.06.002.

Baechler, R., Clerc, M. F., Ulrich, S., \& Benet, S. (2005). Physical changes in heat-treated whole milk powder. Le Lait, 85(4-5), 305-314. http:// dx.doi.org/10.1051/lait:2005016.

Bagga, P., Brisson, G., Baldwin, A., \& Davies, C. E. (2012). Stick-slip behavior of dairy powders: temperature effects. Powder Technology, 223, 46-51. http://dx.doi.org/10.1016/j.powtec.2011.05.015.

Byrne, B., Dunne, G., \& Bolton, D. (2006). Thermal inactivation of Bacillus cereus and Clostridium perfringens vegetative cells and spores in pork luncheon roll. Food Microbiology, 23(8), 803-808. PMid:16943086. http://dx.doi.org/10.1016/j.fm.2006.02.002.

Cappato, L., Ferreira, M., Guimaraes, J., Portela, J., Costa, A., Freitas, M., Cunha, R., Oliveira, C., Mercali, G., Marzack, L., \& Cruz, A. G. (2017). Ohmic heating in dairy processing: Relevant aspects for safety and quality. Trends in Food Science \& Technology, 62, 104-112. http://dx.doi.org/10.1016/j.tifs.2017.01.010.

Chen, C., Michael, M., Phebus, R., Thippareddi, H., Subbiah, J., Birla, S., \& Schmidt, K. (2013). Short communication: Radio frequency dielectric heating of nonfat dry milk affects solubility and whey protein nitrogen index. Journal of Dairy Science, 96(3), 1471-1476. PMid:23332848. http://dx.doi.org/10.3168/jds.2012-6158.

Crowley, S. V., Desautel, B., Gazi, I., Kelly, A. L., Huppertz, T., \& O'Mahony, J. A. (2015). Rehydration characteristics of milk protein concentrate powders. Journal of Food Engineering, 149, 105-113. http://dx.doi.org/10.1016/j.jfoodeng.2014.09.033.

Da Cruz, A. G., Faria, J. A. F., Saad, S. M. I., Bolini, H. M. A., Sant, A. S., \& Cristianini, M. (2010). High pressure processing and pulsed electric fields: potential use in probiotic dairy foods processing. Trends in Food Science \& Technology, 21(10), 483-493. http://dx.doi. org/10.1016/j.tifs.2010.07.006.

Dalsgaard, T. K., Otzen, D., Nielsen, J. H., \& Larsen, L. B. (2007). Changes in structures of milk proteins upon photo-oxidation. Journal of Agricultural and Food Chemistry, 55(26), 10968-10976. PMid:18044829. http://dx.doi.org/10.1021/jf071948g.

Fenaille, F., Parisod, V., Tabet, J. C., \& Guy, P. A. (2005). Carbonylation of milk powder proteins as a consequence of processing conditions. Proteomics, 5(12), 3097-3104. PMid:16038017. http://dx.doi. org/10.1002/pmic.200401139.

Fonseca, C., Bordin, K., Fernandes, A., Rodrigues, C., Corassin, C., Cruz, A., \& Oliveira, C. (2013). Storage of refrigerated raw goat milk affecting the quality of whole milk powder. Journal of Dairy Science, 96(7), 4716-4724. PMid:23664351. http://dx.doi.org/10.3168/ jds.2012-6120.

Fu, X., Huck, D., Makein, L., Armstrong, B., Willen, U., \& Freeman, T. (2012). Effect of particle shape and size on flow properties of lactose powders. Particuology, 10(2), 203-208. http://dx.doi.org/10.1016/j. partic.2011.11.003.

Han, X., Ghoroi, C., To, D., Chen, Y., \& Davé, R. (2011). Simultaneous micronization and surface modification for improvement of flow and dissolution of drug particles. International Journal of Pharmaceutics, 415(1-2), 185-195. PMid:21664954. http://dx.doi.org/10.1016/j. ijpharm.2011.05.070.

Jermann, C., Koutchma, T., Margas, E., Leadley, C., \& Ros-Polski, V. (2015). Mapping trends in novel and emerging food processing technologies around the world. Innovative Food Science \& Emerging Technologies, 31, 14-27. http://dx.doi.org/10.1016/j.ifset.2015.06.007.

Ji, J., Fitzpatrick, J., Cronin, K., Crean, A., \& Miao, S. (2016). Assessment of measurement characteristics for rehydration of milk protein based powders. Food Hydrocolloids, 54, 151-161. http://dx.doi. org/10.1016/j.foodhyd.2015.09.027.

Jiao, S., Deng, Y., Zhong, Y., Wang, D., \& Zhao, Y. (2015). Investigation of radio frequency heating uniformity of wheat kernels by using the developed computer simulation model. Food Research International, 71, 41-49. http://dx.doi.org/10.1016/j.foodres.2015.02.010.

Kasahara, I., Carrasco, V., \& Aguilar, L. (2015). Inactivation of Escherichia coli in goat milk using pulsed ultraviolet light. Journal of Food Engineering, 152, 43-49. http://dx.doi.org/10.1016/j. jfoodeng.2014.11.012. 
Kent, R. M., Fitzgerald, G. F., Hill, C., Stanton, C., \& Ross, R. P. (2015). Novel approaches to improve the intrinsic microbiological safety of powdered infant milk formula. Nutrients, 7(2), 1217-1244. PMid:25685987. http://dx.doi.org/10.3390/nu7021217.

Kim, E. H.-J., Chen, X. D., \& Pearce, D. (2005). Effect of surface composition on the flowability of industrial spray-dried dairy powders. Colloids and Surfaces. B, Biointerfaces, 46(3), 182-187. PMid:16337780. http://dx.doi.org/10.1016/j.colsurfb.2005.11.005.

Kim, E. H.-J., Dong, C. X., \& Pearce, D. (2003). On the mechanisms of surface formation and the surface compositions of industrial milk powders. Drying Technology, 21(2), 265-278. http://dx.doi. org/10.1081/DRT-120017747.

Leturia, M., Benali, M., Lagarde, S., Ronga, I., \& Saleh, K. (2014). Characterization of flow properties of cohesive powders: a comparative study of traditional and new testing methods. Powder Technology, 253, 406-423. http://dx.doi.org/10.1016/j.powtec.2013.11.045.

Luechapattanaporn, K., Wang, Y., Wang, J., Tang, J., Hallberg, L. M., \& Dunne, C. P. (2005). Sterilization of scrambled eggs in military polymeric trays by radio frequency energy. Journal of Food Science, 70(4), E288-E294. http://dx.doi.org/10.1111/j.1365-2621.2005. tb07185.x.

Marabi, A., Raemy, A., Bauwens, I., Burbidge, A., Wallach, R., \& Saguy, I. (2008). Effect of fat content on the dissolution enthalpy and kinetics of a model food powder. Journal of Food Engineering, 85(4), 518-527. http://dx.doi.org/10.1016/j.jfoodeng.2007.08.012.
Marra, F., Zhang, L., \& Lyng, J. G. (2009). Radio frequency treatment of foods: review of recent advances. Journal of Food Engineering, 91(4), 497-508. http://dx.doi.org/10.1016/j.jfoodeng.2008.10.015.

Michael, M., Phebus, R., Thippareddi, H., Subbiah, J., Birla, S., \& Schmidt, K. (2014). Validation of radio-frequency dielectric heating system for destruction of Cronobacter sakazakii and Salmonella species in nonfat dry milk. Journal of Dairy Science, 97(12), 7316-7324. PMid:25262184. http://dx.doi.org/10.3168/jds.2013-7862.

Scheidegger, D., Pecora, R., Radici, P., \& Kivatinitz, S. (2010). Protein oxidative changes in whole and skim milk after ultraviolet or fluorescent light exposure. Journal of Dairy Science, 93(11), 51015109. PMid:20965324. http://dx.doi.org/10.3168/jds.2010-3513.

Scheidegger, D., Radici, P. M., Vergara-Roig, V. A., Bosio, N. S., Pesce, S. F., Pecora, R. P., Romano, J. C., \& Kivatinitz, S. C. (2013). Evaluation of milk powder quality by protein oxidative modifications. Journal of Dairy Science, 96(6), 3414-3423. PMid:23548289. http://dx.doi. org/10.3168/jds.2012-5774.

Semagoto, H. M., Liu, D., Koboyatau, K., Hu, J., Lu, N., Liu, X., Regenstein, J. M., \& Zhou, P. (2014). Effects of UV induced photo-oxidation on the physicochemical properties of milk protein concentrate. Food Research International, 62, 580-588. http://dx.doi.org/10.1016/j. foodres.2014.04.012.

Sormoli, M. E., \& Langrish, T. A. (2015). Moisture sorption isotherms and net isosteric heat of sorption for spray-dried pure orange juice powder. Lebensmittel-Wissenschaft + Technologie, 62(1), 875-882. http://dx.doi.org/10.1016/j.lwt.2014.09.064. 